\title{
A SURVEY OF MAJOR ETHNO MEDICINAL PLANTS OF KANO NORTH, NIGERIA, THEIR KNOWLEDGE AND USES BY TRADITIONAL HEALERS
}

Sani H. Dambatta and Aliyu, B.S.

Department of Forestry Technology, Audu Bako College of Agriculture Dambatta, P.M.B 3159 Kano State Department of Biological Sciences, Bayero University, Kano.

*Correspondence author

\begin{abstract}
An ethno botanical survey of major ethnomedicinal plants was carried out in the study area (Kano north senatorial district, Nigeria), their knowledge and uses by the local healers was determined. Data was obtained through the use of interviewer administered questionnaires, distributed at random to the traditional healers as the target respondents. Research shows that various plant species from 25 families were reported to be used in the treatment of various human ailments. Majority of these plants (73.2\%) were wild, and $40 \%$ were harvested mainly for their leaves. Most of the plants were trees (44\%). About $45.2 \%$ have been reported to be used in dry form. Concoction was the major method of preparation of the medicinal plants (46\%). The most reported threat to the availability of medicinal plants was deforestation (43.6\%). Many additives like edible oil, honey, butter, porridge, garlic were used in almost $58 \%$ of the remedy preparations. In addition, more than one medicinal plant species were used more frequently than the use of single species for medicinal preparations.
\end{abstract}

Keywords: Ethnobotany, Senatorial zone, Knowledge, Use.

\section{INTRODUCTION}

According to the world health organisation (WHO), more than $80 \%$ of the world population relies on traditional medicine for their primary health care (Veeramuthu 2006). Use of herbal medicine in Nigeria represents a long history of human interaction with the environment. Plants used in traditional medicine contain a wide range of substances that can be used to treat chronic as well as infectious diseases. A vast knowledge of how to use the plants against various illness may be expected to be accumulated in areas where the use of medicinal plants is still of great importance ( Diallo, 1999 ).

Rural communities in particular depend on plant resources mainly for herbal medicine, food, forage, construction of dwellings making household implement and fuel and shade (Veeramuthu 2006). The use of medicinal plants as traditional medicine is well known in rural areas of many developing countries. Traditional healers claim that their medicine is cheaper and more effective than modern medicine. The indigenous traditional knowledge of medicinal plants of various communities where it has been transmitted orally for centuries is fast disappearing due to the advent of modern technology and transformation of traditional culture. Moreover, traditional healers are also decreasing in number and the younger generation are not interested to carry on this tradition and in most cases the knowledge has not been recorded, as such there is great danger that this cultural heritage and basis for future research may be lost forever. Therefore it becomes the responsibility of the scientific community to unravel this information and to document it for availability to the whole world for the benefit of human beings (Rajadurai, 2004). The Hausa land like Kano is not left behind in the use of ethno medicinal plants where various groups of herbalist or consultant use different varieties of plants in the treatment of physical, mental, and social diseases. The healers may be sedentary or mobile, the latter following a regular circuit within a periodic market or moving randomly from village to village (Jinju, 1990). This paper was aimed at determining and assessing the major ethno medicinal plants of the study area so as to document the indigenous knowledge and use of ethno medicinal plants by local healers to treat various human ailments in the study area.

\section{MATERIALS AND METHODS}

An ethno botanical survey was conducted in the study area (Kano north senatorial district), located between latitude $10^{\circ}-30^{\circ} \mathrm{N}$ and $13^{\circ}-15 \mathrm{~S}$. It has the Sudan savannah type of climate and vegetation that gives way to semi arid condition. The area is part of Hausa land where ethno medicine is recognised and highly practiced (Hussain and Deeni 1991). The area comprises of about thirteen local government areas. However, five local governments were selected based on geographical spread, namely Dambatta, Tsanyawa, Tofa, Gezawa, and Gwarzo. Data was collected through the use of interviewer administered questionnaires, and oral interviews with traditional herbalists as the target respondents. 
Two hundred and fifty (250) questionnaires were administered at random within the study area, and same number of questionnaires were retrieved. Data on human ailment treated by the use of plants, name of plant, habit of plant, degree of management, plant part used, how plant part is used, method of preparation for medicinal use, mode of administration, reported threat to the availability of medicinal plants were all recorded. Data was analysed using descriptive statistics. Chi square test was also employed to find the relationship with regard to their degree of management, plant part used, how plant part is used, mode of preparation and administration.

\section{RESULTS}

Results showed that various plant species from 25 families were reported to be used in the treatment of various human ailments in the study area (Table 1). Majority of the plants (73.2\%) were wild, whereas few number of species $(8.8 \%)$ of the reported medicinal plants were cultivated, and other species constituting (18\%) were indicated as wild/cultivated (Figure 3). Significant difference was observed in the degree of management $\left(x^{2}=501.9, d f=2\right.$, alpha $=0.05, p$ value $=5.991)$. Result also shows that the plants growth form and habit were trees (with $44 \%$ ), shrubs $(26.4 \%)$ and herbs $(29.6 \%)$ (Figure 2 ). Most of the reported medicinal plants (about $40 \%$ ) were harvested for their leaves. With regards to mode of preparations, preparation from the roots constitutes (12.8\%) stem (27.2\%), flower/seeds $(8 \%)$, while complete plants have been reported to be used also $(12 \%)$ (Figure 4$)$.
Plant parts used in the medicinal preparation shows significant difference $\left(x^{2}=601.2, d f=4\right.$, alpha $=0.05, p$ value $=9.488)$. About $45.2 \%$ of the medicinal plants have been reported to be used in dry form, 33.2\% fresh form, relatively few $(21.6 \%)$ were reported to be used in fresh and dried form (Figure 5). Various preparations have been reported to be used with concoction taking the highest percentage of $46 \%$, decoction $(22.8 \%)$, steaming (8.8\%), infusion (13.6\%), other preparations constitute only $8.8 \%$ (Figure 6 ). There was significant difference observed in the mode of medicinal preparations of the medicinal plants in the study area $\left(x^{2}=592.76\right.$, $\mathrm{df}=4$, alpha $=0.05, \mathrm{p}$ value $=9.488)$. Based on the information gathered, the most reported method of application was oral $(67.6 \%)$, topical $(25.2 \%)$ and sniffing/inhaling (7.2\%) (Figure 7). Significant difference was also observed with regard to the mode of administration of the medicinal preparations $\left(x^{2}=375.1, d f=2\right.$, alpha $=$ $0.05, p$ value 5.991). The most reported threat to medicinal plants in the study area were deforestation $(43.6 \%)$, fire $(30 \%)$, pests and diseases $(9.6 \%)$, while $16.8 \%$ were reported to face no threat to their availability (Figure 8).

Many additives like edible oil, honey, porridge (Fura), butter (man shanu) and garlic were used in addition to the plant parts in almost $58 \%$ of the remedy preparation. Moreover, more than one medicinal plant species were used more frequently than the use of single species for medicinal preparation.

Table 1: Some major ethnomedicinal plants of Kano North, their Botanical/local Names, Part used, and Medicinal uses

\begin{tabular}{|c|c|c|c|c|}
\hline Plant name (Botanical) & Local name & Family & $\begin{array}{l}\text { Part } \\
\text { used }\end{array}$ & Medicinal uses \\
\hline Acacia ataxacantha & Bagaruwar kasa & Luthraceae & Whole & $\begin{array}{l}\text { excessive cough, and } \\
\text { yellow fever. }\end{array}$ \\
\hline Allium sepa & Albasa & Liliaceae & Stem bulb & $\begin{array}{l}\text { Hypertension, measles } \\
\text { and cough }\end{array}$ \\
\hline Allium sativum & Tafarnuwa & Liliaceae & Stem bulb & Catarrh, cold, cough \\
\hline Anogeissuss leiocapus & Marke & Combretaceae & Stem-bark & $\begin{array}{l}\text { Stomach trouble, cough, } \\
\text { diarrhoea }\end{array}$ \\
\hline Annona senegalensis & Gwandar daji & Anonaceae & Stem & Snake bite, hernia \\
\hline Azadiracta indica & Darbejiya & Meliaceae & Leaf & Yellow fever \\
\hline Boswelia dalzelia & Hano & Balnitaceae & leaf & Yellow fever \\
\hline Boswelia odorata & Ararrabi & Burceraceae & Stem & $\begin{array}{l}\text { Malaria in children, pile, } \\
\text { yellow fever, haemorrhoid }\end{array}$ \\
\hline Calotropis procera & Tumfafiya & Asclepiadaceae & leaf & $\begin{array}{l}\text { Scorpion sting, } \\
\text { finger ache (witlow) }\end{array}$ \\
\hline Cassia italica & Filasko & Legumenoceae & leaf & $\begin{array}{l}\text { Cold (running nose), } \\
\text { Rheumatism }\end{array}$ \\
\hline Cassia singuena & Runfu & Caesalpinaceae & Leaf/root & Stomach ache, Cancer \\
\hline Cassia tora & Tafasa & Legumenoceae & Leaf & Pile and stomach trouble \\
\hline Cassia occidentalis & Rai-rai & Legumenoceae & Leaf & Rheumatism \\
\hline Cochlerspernum tinctorium & Rawaya & Cochlospermeceae & Root & Yellow fever \\
\hline Combretum micranthum & Geza & Combretaceae & Leaf & $\begin{array}{l}\text { Dysentry, abdominal } \\
\text { pain in nursing mother }\end{array}$ \\
\hline Curcubita maxima & Kabewa & Curcubitaceae & stem & Skin diseases \\
\hline Dichrostachys peneria & Dundu & Legumenoceae & Leaf & Tooth ache \\
\hline
\end{tabular}


Table 1 continue

\begin{tabular}{|c|c|c|c|c|}
\hline Plant name (Botanical) & Local name & Family & $\begin{array}{l}\text { Part } \\
\text { used }\end{array}$ & Medicinal uses \\
\hline Diospyros mesipiliformis & Kanya & Ebanaceaea & Fruits & pile and haemorrhoid \\
\hline Entandra africana & Tawatsa & Legumenoceae & Root & $\begin{array}{l}\text { Gonorrhoea and } \\
\text { abdominal pain in woman }\end{array}$ \\
\hline Erythrina senegalensis & Minjirya & Papilonaceae & Stem & Yellow fever \\
\hline Euphorbia hirta & Nonon kurciya & Euphorbiaceae & Stem & $\begin{array}{l}\text { Dandruff, sores in the } \\
\text { mouth }\end{array}$ \\
\hline Ficus thoningii & Chediya & Moraceae & Leaf & Stomach offset \\
\hline Ficus abustifolia & Yandi & Moraceae & Leaf & Oedema \\
\hline Ficus ingens & Kawari & Moraceae & Stem & Diarrhoea \\
\hline Ficus platyphylla & Gamji & Moraceae & Stem-bark & Stomach trouble and pile \\
\hline Gueria senegalensis & Sabara & Combretaceae & Leaf & $\begin{array}{l}\text { Dysentery, diarrhoea, } \\
\text { pile and stomach ach. }\end{array}$ \\
\hline Lanea acida & Faru & Anacardiceae & Stem bark & Yellow fever and pile \\
\hline Lowsonia inermis & Lalle & Lyhtraceae & Root & $\begin{array}{l}\text { Vomiting, abortion and } \\
\text { witlow }\end{array}$ \\
\hline Leptademia hastata & Yadiya & Asclepidaceae & whole & $\begin{array}{l}\text { Hypertension, catarrh and } \\
\text { skin diseases }\end{array}$ \\
\hline Mitracarpus scaber & Gogamasu & Rubiaceae & Whole & $\begin{array}{l}\text { Eczema and other skin } \\
\text { Diseases }\end{array}$ \\
\hline Myterus senegalensis & Namijin tsada & Celastraceae & Leaf & $\begin{array}{l}\text { Asthma, cough, remedy } \\
\text { for sores on tongue }\end{array}$ \\
\hline Perinaria macrophylla & Gawasa & Chrysobalanaceae & Stem bark & Stomach trouble \\
\hline Prosopis africana & Kirya & Mimoceae & Stem/pod & Pile and haemorrhoid \\
\hline Piliostigma reticulata & Kalgo & Legumenoceae & Stem & Pile, cough \\
\hline Phoenix dactylifera & Dabino & Palmae & Fruit/seed & Worms, bleeding \\
\hline Steruspernum kunthianum & Sansami & Bignoniaceae & Stem & Yellow fever \\
\hline Sarcocephalus russegeri & Tafashiya & Rubiaceae & Stem & $\begin{array}{l}\text { Yellow fever } \\
\text { tuberculosis }\end{array}$ \\
\hline Sclerocarya birrea & Danya & Anacardiaceae & Stem bark & Diarrhoea, pile \\
\hline Strycnosa spinosa & Kokiya & Loganiceae & Fruit & Eye ache \\
\hline Hankufa & Sterculaceae & Root & Root & $\begin{array}{l}\text { Dysentery and other } \\
\text { stomach offset }\end{array}$ \\
\hline
\end{tabular}

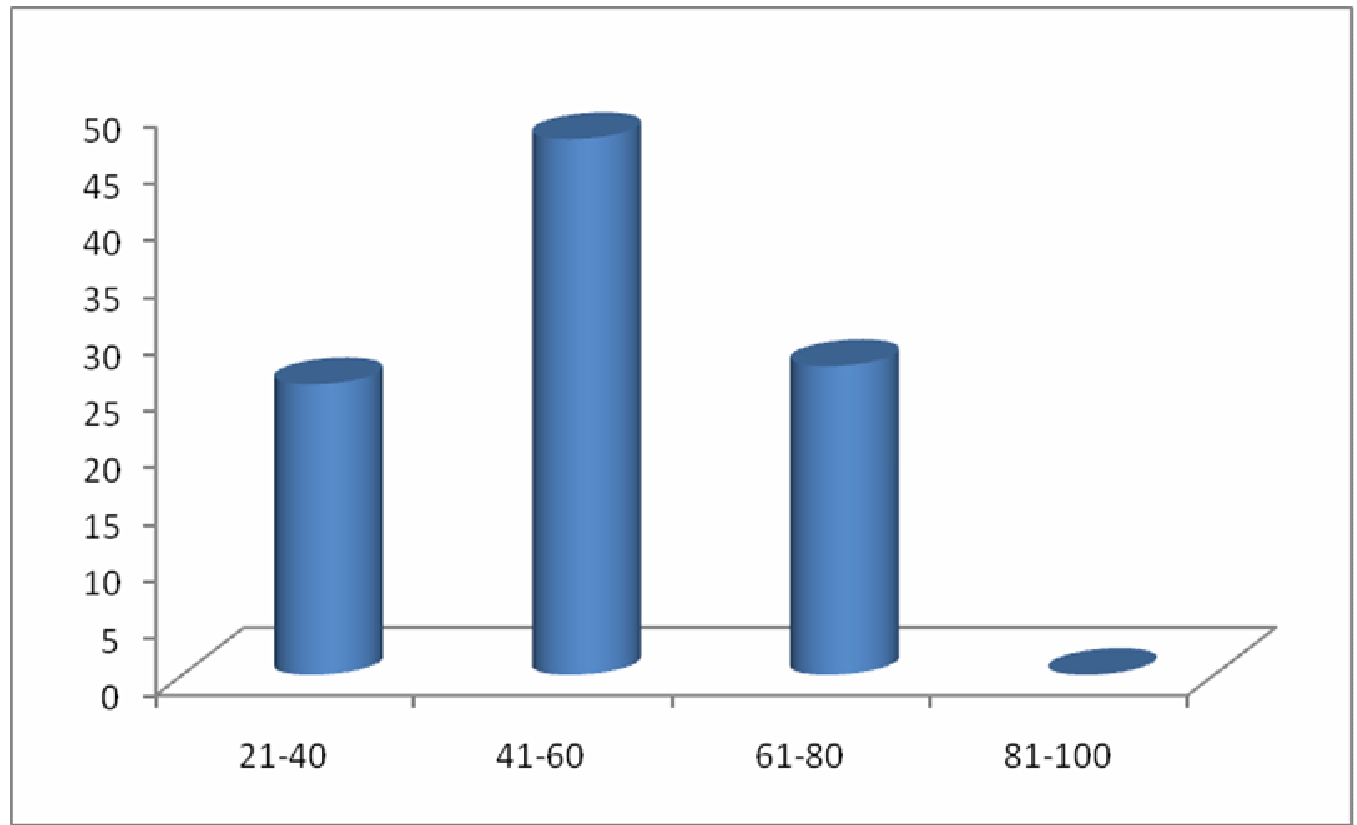

Figure 1: Age distribution of the respondents surveyed in the Kano North senatorial district (2010) 


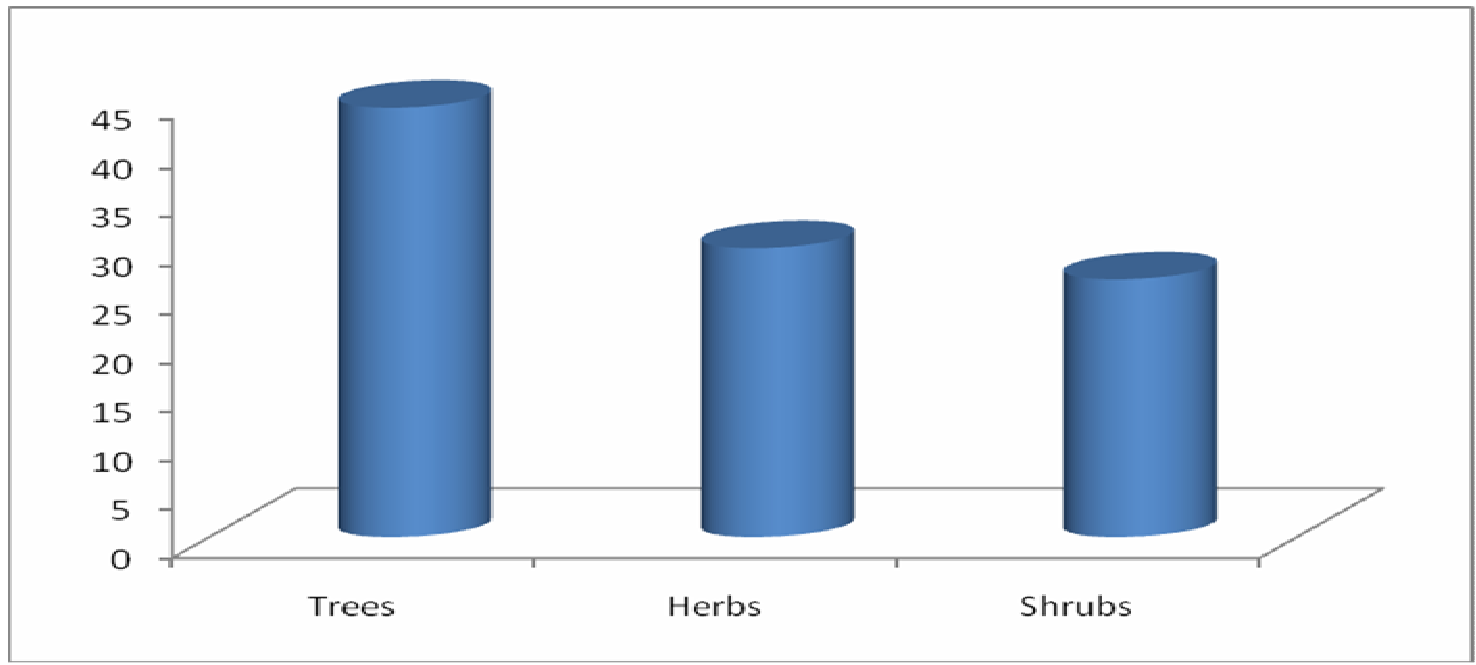

Figure 2: Growth form and habit of reported medicinal plants surveyed in the Kano North Senatorial district (2010).

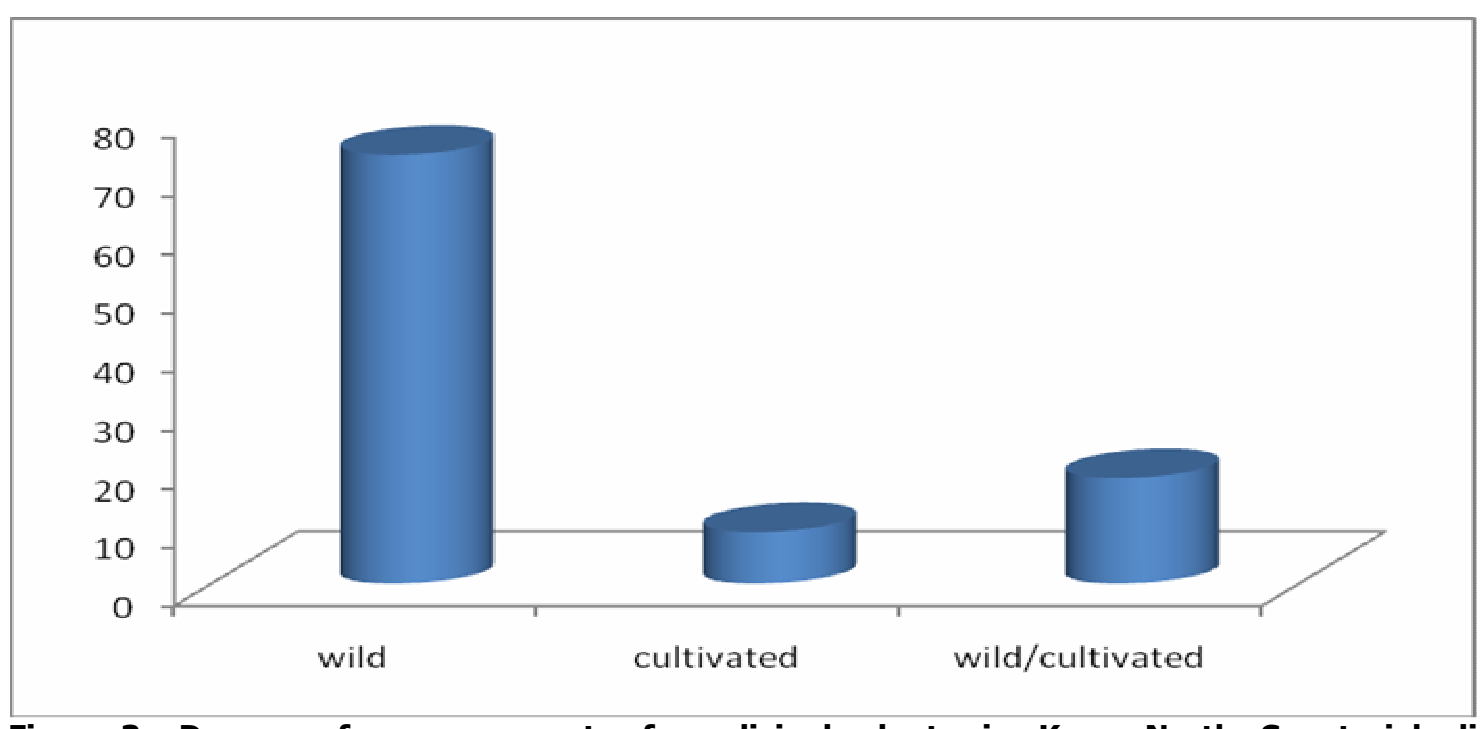

Figure 3: Degree of management of medicinal plants in Kano North Senatorial districts surveyed (2010).

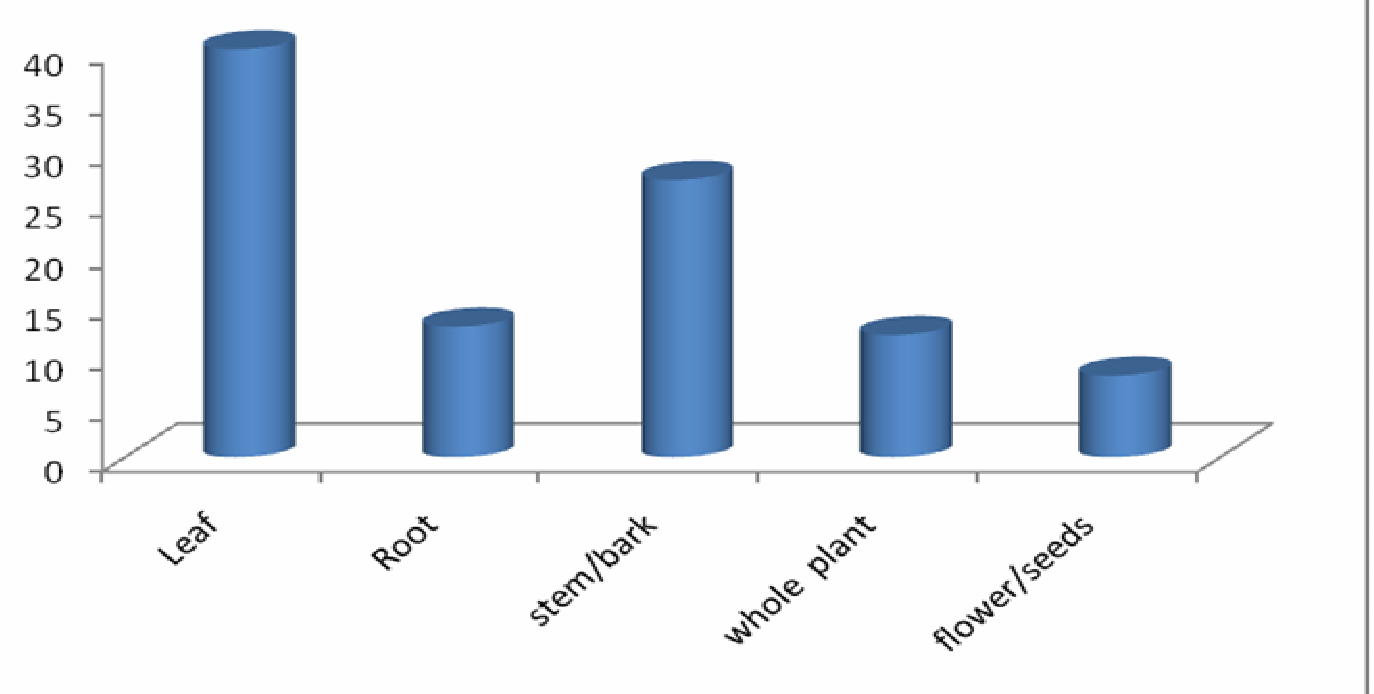

Figure 4: Part of plant used in ethnomedicinal preparations, surveyed in Kano North Senatorial district (2010). 


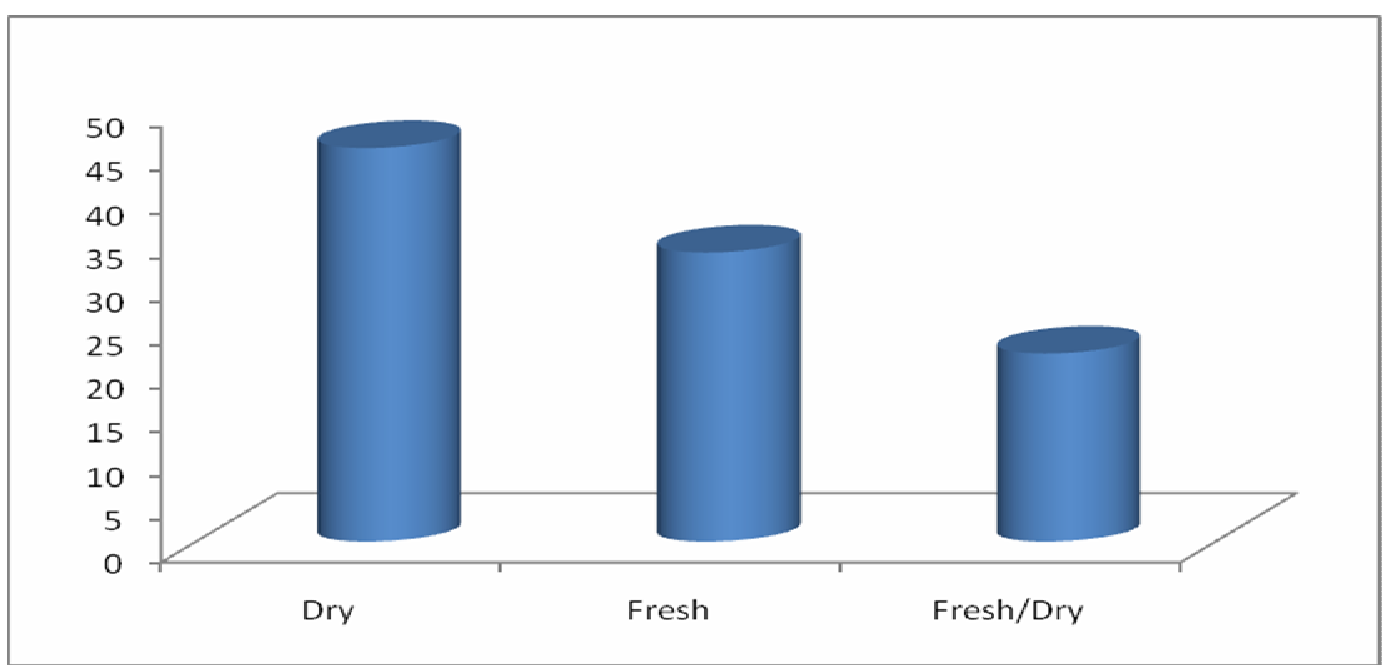

Figure 5: Form in which plant part is used in ethnomedicinal preparations surveyed in th Kano North senatorial district (2010).

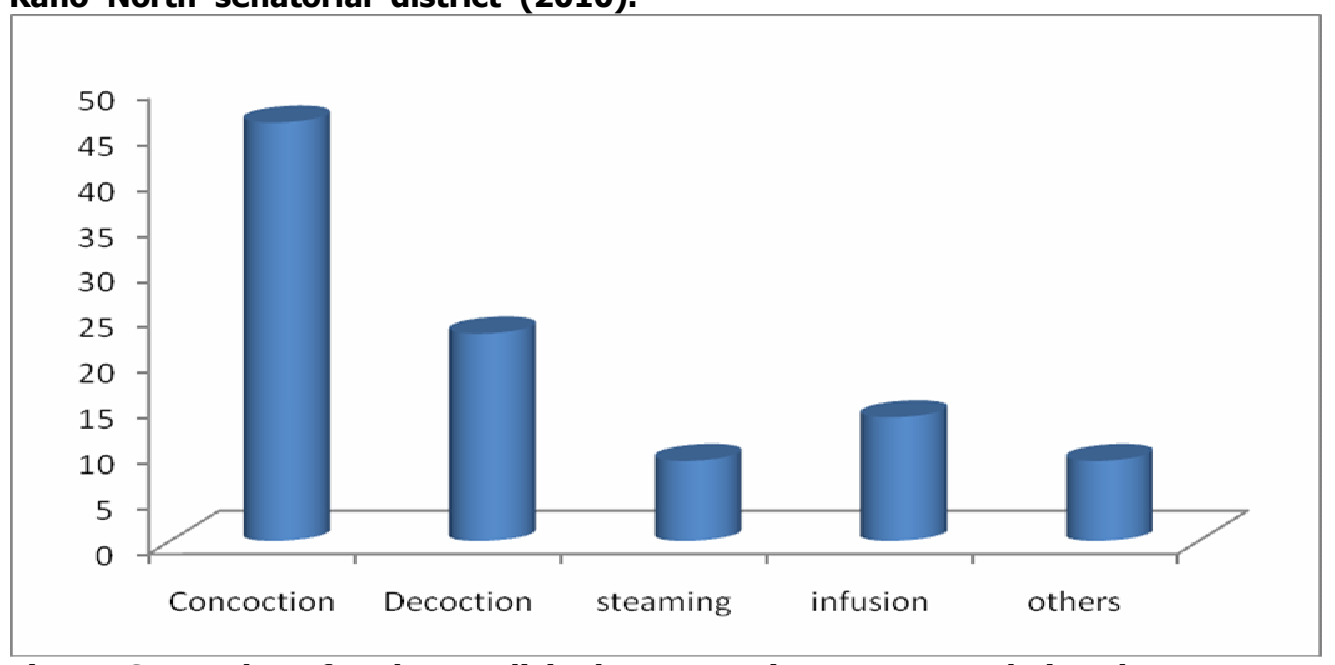

Figure 6: Mode of ethnomedicinal preparations, surveyed in the Kano North Senatorial district (2010).

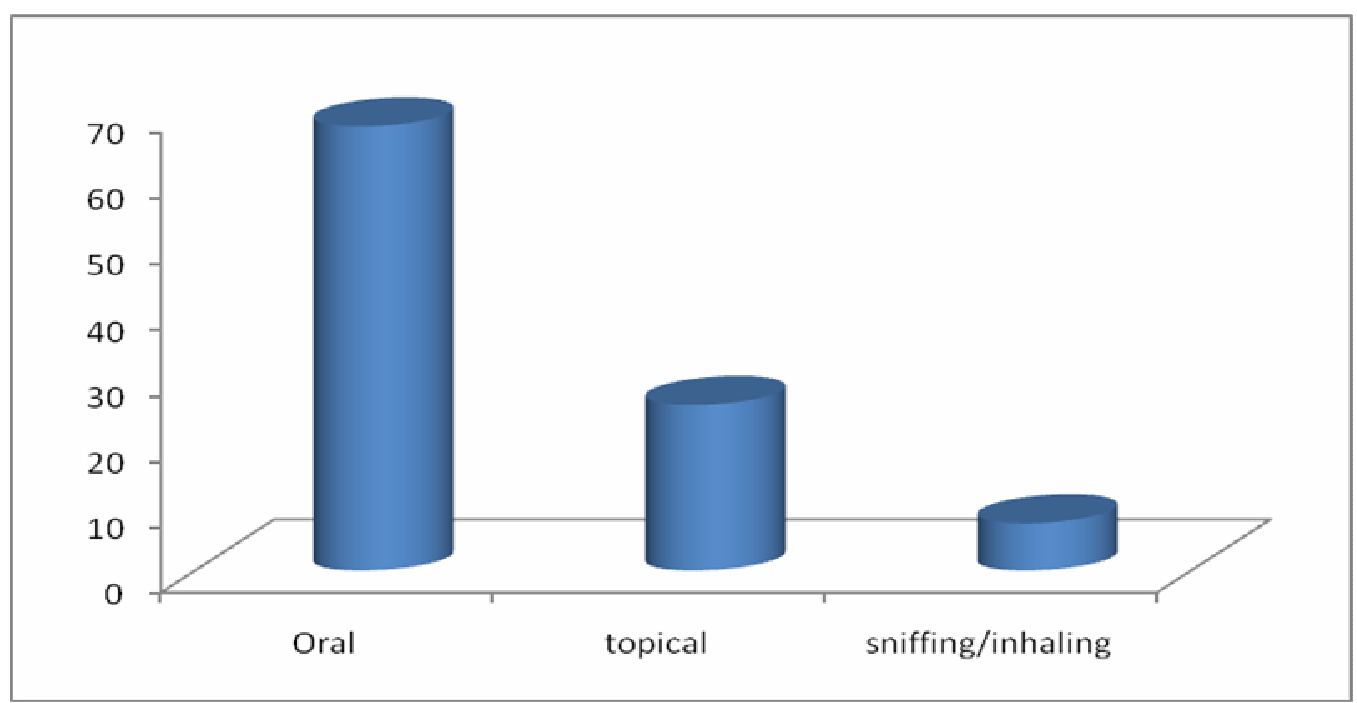

Figure 7: Route of administration of preparations from ethnomedicinal plants surveyed in the Kano North Senatorial district (2010). 


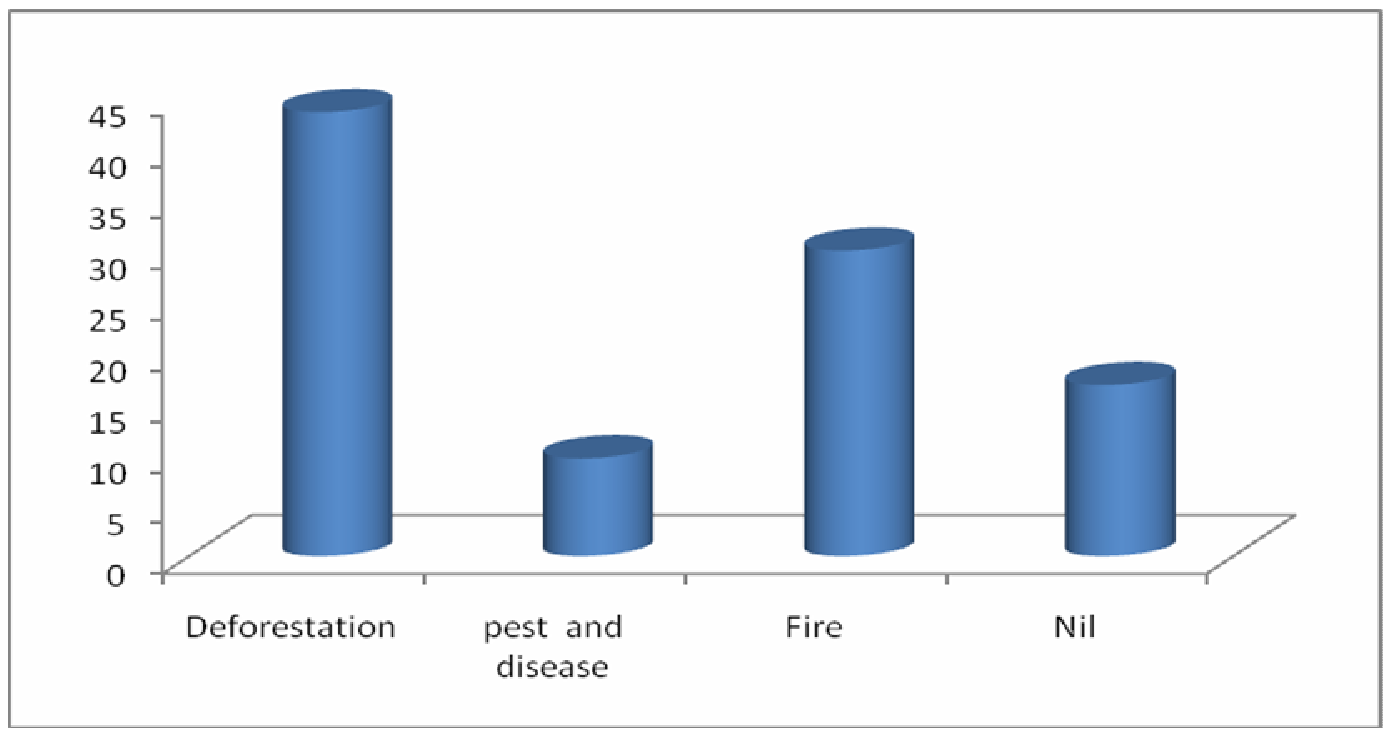

Figure 8: Reported threats to the availability of medicinal plants in Kano North Senatorial districts surveyed (2010).

\section{DISCUSSIONS}

Available literature consulted shows that, the use of ethno medicinal plant to treat various ailments was not documented in the study area.

Results of the study shows that most of the ethno medicinal plants used were reported as wild, similar research was conducted in other countries like Uganda and Ethiopia were medicinal plants used in ethno medicine were reported as wild (Haile, And Delenasaw, 2007). This clearly indicated that most of the ethno medicinal plants are not yet cultivated by the traditional herbalist.

Result of the study also shows that majority of the plants used in ethno medicine in the study area were trees. This may be due to the fact that this growth form is available in almost all seasons and in addition are not affected by seasonal variations as reported by Albuquerque (2006).

Leaves were found to be the most reported plant part used by the healers for the preparation of various medications in the study area. This correspond with the findings of other ethno medicine studies in Africa like Uganda, Ethiopia and Mali where it was reported that most of the plant parts used in different preparations for remedy were leaves ( Tagola, and Diallo 2005).

More than one plant species have been reported to be used by healers in remedy preparation for various ailments. This could be attributed to additives or synergistic effect that they could have during treatment (Haile, and Delenasaw, 2007). While some plants are prepared singly and correspond with other findings in Bolivia (Macia, 2005). Various additives such as edible oil, porridge, honey, etc were used in remedy preparations.

Following the interview with traditional healers it has been reported that majority were found to have poor knowledge of dosage and antidote while giving prescription of remedy to the patients, and most of preparations were said to have no side effect except vomiting and in rare cases watery stool and this may be attributed to the low toxicity of medicinal plant species used by the local herbalist (Haile and delenasaw, 2007).

The major threat to the availability of medicinal plant was deforestation. This could be attributed to the additional values of the majority of ethno medicinal plants in the study area as well as current high demand for fuel wood as an energy source. Therefore an effort should be made to conserve the diversity of these vital resources.

The indigenous knowledge among the traditional healers with regard to their age shows that majority were of old age, this reveals that, knowledge transfer to the younger generation was very poor, they seem to keep the knowledge with them either for the sake of secrecy or due to apathy but the younger generation to traditional knowledge.

\section{CONCLUSION}

In this research, many plants of medicinal importance more particularly those used in ethnomedicine in the study area were determined, assessed, and finally recorded and documented. The documentation of the indigenous knowledge of the use of ethnomedicinal plants will greatly help in preventing the erosion of such knowledge, as knowledge transfer was oral and the practitioners are at their old age, and in addition the younger generation are not interested to carry on the practice. From the result of the research majority of the plants species were reported to be rare and abundant, this will attract an urgent attention towards conserving such vital resources, so as to optimize their use in the primary health care system. 
According to the literature review, some of the plants of the study area were found to have some bioactive compounds and biological activities. Therefore, further studies of the above should also be conducted so that they can be utilized in the synthesis of conventional drugs.

\section{REFERENCES}

Albuquerque, UP. (2006). Re-examining hypothesis concerning the use and knowledge of medicinal plants: a study in the Caatinga vegetation of NE Brazil. Journal of ethno biology and ethno medicine (2006). 2:30.

Diallo, D. (1999). An ethno botanical survey of herbal drugs of Gourma district of mali. Journal of pharmaceutical biology 37:8091.

Rajadurai, M. (2004). ethno medicinal plants used by traditional healers of pharmalai hills india. Journal of ethno medicine

Hussain H. and Deeni Y. (1991). Plant in Kano ethno medicine: screening for antimicrobial activity and alkaloid. Pharmaceutical biology vol. 29(1):15-56
Haile, Y. and Delenasaw, Y. (2007). Traditional medicinal plants knowledge and uses by local healers in Sekoru district jimma zone Ethiopia. Journal of ethno biology and ethno medicine 3:24.

Jinju, M. (1990). African traditional medicine. A case study of Hausa medicinal plants and therapy. Gaskiya cooperation limited, Zaria. Nigeria pp 16-17

Macia M.J. (2005) An ethno botanical survey of medicinal plants commercialized in the market la paz Bolivia. Jouranal of ethnopharmacology 97:337-350

Togola, A. and Diallo, D. (2005). Ethnopharmacological survey of different uses of seven medicinal plants from mali (West Africa) in the region of Doila, Kolokaini, and Siby. Jounal of ethno biology and ethno medicine 1:7

Veeramuthu D. Antibacterial activity of some ethnomedicinal plants used by paliya tribe from Tamil Nadu, India. Entomology Research institute, loyala college. 6:35 